\title{
Sulam Bayangan Industry Possibility Improvement Strategy
}

\author{
Elva Dona ${ }^{1}$, Rusda Khairati Idrus ${ }^{2}$, Henryanto Abaharis ${ }^{3}$, Novia Indriani", \\ Eka Hendrayani ${ }^{5}$, and Romi Susanto ${ }^{6}$ \\ ${ }^{1}$ AKBP Padang \\ 'UNAND \\ 3STIE"KBP" \\ ${ }^{4}$ UIN Imam Bonjol \\ ${ }^{5}$ AMIK Kosgoro
}

\section{Abstract}

The purpose of this work was identify the critically problems faced by the Sulam bayangan industry and formulated strategies to address them. The seven groups of Sulam Bayanagan in the kanagarian barung barung balantai were conducted in-depth interviews and used questionnaires with a SWOT analysis of potential internal and

Corresponding Author:

Elva Dona

mifthah02@gmail.com

Received: 18 January 2019

Accepted: 24 March 2019

Published: 31 March 2019

Publishing services provided by

Knowledge E

(c) Elva Dona et al. This article is distributed under the terms of the Creative Commons

Attribution License, which permits unrestricted use and redistribution provided that the original author and source are credited.

Selection and Peer-review under the responsibility of the First ELEHIC Conference Committee. external analysis evaluations. The main problems found are the limited stock of Sulam Bayangan and marketing problems. The recommended strategy was to maximize the role of local government and form a community together and increase the skills of the priciples and maximize the use of social media for promotion. This effort can make the shadow embroidery industry a superior product of Pesisir Selatan.

Keywords: SWOT, Improvement strategy, SME'S

\section{Intoduction}

Sulam Bayangan in the barung barung balantai regency is a work of the creation of South Pesisir community which was originally born in Kenagarian Barung-Barung Balantai SubDistrict Koto XI Tarusan Pesisir Selatan of West Sumatera Province, at the beginning of creation of the creation of this Nagari children is producing only Mukenah Calligraphy which is designed with various Arabic calligraphy which is formed in embroidery paste by using a puncture trace, so that it can produce a unique copyrighted work. Along with its development in accordance with the times, the people of the Dutch Barung Barung Balantai created new innovations in the form of clothing that was designed specifically with more diverse motives, not only calligraphy but plant motifs with a solid color match so that it was more interesting and unique. is in the process of using hand stitches. 
At present there are 200 embroidery craftsmen who each have their own embroidery characteristics, which are divided into 12 (twelve) groups.

Shadow embroidering skills are skills passed down by parents to their daughters in kanagarian barung barung balantai which was originally a calligraphy motif on mukenah (the results of interviews with the canagarian community of barung barung balantai). According to Widyasari, (2014) "Embroidering is the art of embroidery that makes a fabric surface appearance becomes more beautiful using the yarn in a decorative". Further Widyasari, (2014) "Embroidery is the result of decorating cloth or other materials with sewing tips using needles and threads". Strategy is an overall approach relating to the implementation of the idea, planning and education of an activity within a certain time. In a good strategy there is coordination of the work team, having a theme, identifying supporting factors that are in accordance with the principles of implementing ideas rationally, efficiently in funding, and having tactics to achieve goals effectively. According to Cahyani, [1] strategy is a choice of what the organization wants to achieve in the future and how to achieve the desired direction.

Desiyanti [2] said that there are three important elements that need to be considered for the success of a strategy, namely: 1) Strategy must be consistent with the competitive environment 2) Strategy must be realistic with internal company 3) Strategy must be carried out with great care.

According to Bagindo et al, [3] strategies can be formulated through the following main stages: 1) Direction Analysis, which is to determine the vision, mission and long-term goals the organization wants to achieve. 2) Situation Analysis, which is the stage to read the situation and determine the strengths-weaknesses-the threats that will form the basis of strategy formulation. 3) Implementation of strategies, namely stages for identifying alternatives and choosing strategies that will be carried out by the organization.

According to Primadani et al, [4] strategic management is an art and science that is useful for formulating, implementing and evaluating cross-functional decisions so that an organization can achieve its objectives. Meanwhile, according to Yulianti, [5] strategic management is a set of decisions and actions that can produce a formulation and implementation plan that is designed to achieve company goals.

External Factor Evaluation Matrix (EFE) This matrix helps strategists summarize and evaluate external environmental information. There are five steps in developing the EFE matrix: 1) List the external factors identified in the external audit process. Search between 10 and 20 factors including opportunities and threats that affect the company and its industry. List of opportunities first then threats. 2) Give weight to each factor from 0.0 (not important) to 1.0 (very important). The weight indicates the relative importance of 
these factors to succeed in the industry. The total weight given to the above factor must be equal to 1.0. 3) Give a rating of 1 to 4 on each factor of critical success with notes 4 = superior answers, 3 = answers above average, 2 = average answers, 1 = bad answers. The ratings are based on the state of the company while the weights in step 2 are based on the industry. 4) Multiply each factor weight by ranking to determine the weighted value. 5) Add the weighted values for each variable to determine the total weighted value for the organization. Internal Environmental Analysis, Is an environmental analysis of the environment in the company that will affect the strengths and weaknesses of the company. In the formulation of the strategy, the company is expected to be able to carefully identify and evaluate all of its internal variables, to find out the strength (strength), and its weakness (weakness). Internal factor analysis is basically an attempt to disaggregate a company into various discrete variables and / or activities that seem to be separated from one another. Power is called if internal variables are evaluated to make a company have certain advantages. The company is able to do things better and or cheaper than its competitors. It is called a weakness if the company is not able to work on something that can be done well and or cheaper by its competitors.

Internal Factor Evaluation Matrix (EFI), the closing step in carrying out internal audit is to make an internal factor evaluation matrix.

\subsection{Matching phase}

According to Suprajang, (2015), the TOWS Matrix is an important matching tool that helps managers develop four types of strategies, namely:

\subsubsection{SO strategy}

This strategy uses the power to take advantage of opportunities. It is a favorable situation, the organization has strengths and opportunities, so it can utilize the power to reach the opportunities that exist.

\subsubsection{WO strategy}

This strategy overcomes weaknesses by taking advantage of opportunities. Organizations have internal weaknesses, but have the opportunity to seize the opportunities that exist, so that weaknesses must be overcome immediately to achieve opportunities 


\subsubsection{Strategy ST}

This strategy uses power to avoid threats. Despite facing external threats, the organization still has internal power to overcome these threats.

\subsubsection{Strategy WT}

This strategy minimizes weaknesses and avoids threats. It is a very unfavorable situation, the organization has weaknesses and gets threats.

Internal-External Matrix (I-E), IE Matrix is based on two key dimensions, total EFI values weighted on the $x$-axis and the total EFE value weighted on the $y$-axis. IE matrix is divided into three main parts, which have different strategy impact. First, divisions that enter cells I, II or IV can be called grow and develop. Intensive or integrative strategies may be right for all of these divisions. Second, divisions that enter cell III, V or VI can be managed with a retention and maintenance strategy. The general division that enters cell VI, VII or IX is harvested or divested. Successful organizations can reach business portfolios positioned in or around cell I in the IE matrix (Bima Iman Destratama, 2015).

Decision Stage Through the Quantitative Strategic Planning / QSPM Matrix, QSPMis stage 3 of the strategy formulation analysis framework. This technique targets to show which alternative strategy is best. QSPM uses input from phase 1 and stage 2 analysis to decide which strategies are most effective among the existing strategic alternatives $[6,7]$

\section{Research Methods}

The research will be carried out using a type of qualitative research with descriptive methods to analyze and interpret the conditions or conditions of shadow embroidery industry barung barung balantai so that policies, strategies and decisions can be taken to make corrective actions that are more specific and realistic. internal and external from the industry or company. Internal factors include marketing, production, financing and human resources. While external factors in the form of economic, political, social and cultural conditions Secondary data were obtained from the trade service and MSMEs in the Pesisir Selatan district while the primary data was obtained through interviews with group leaders and shadow embroidery craftsmen Barung Barung Balantai.

Data analysis method is carried out by collecting secondary and primary data, the analysis of external and intenal environments that will find opportunities and threats as 
well as the strengths and weaknesses of the shadow embroidery industry in barung barung balantai

Stage Input Is the initial stage in formulating the industry strategy for shadow embroidery barung barung balantai. At this stage several steps need to be carried out as follows: 1) External Environmental Analysis which consists of the economic, technological, social and environmental environment.2) Internal Environmental Analysis consisting of marketing, production, financing and human resources.

Data collection of external and internal factors that affect the shadow embroidery industry barung barung balantai other than obtained through secondary data, also obtained through interviews conducted with the chairman of the group and artisans shadow embroidery barungbarung balantai.

\subsection{Matching phase}

In this matching stage, the TOWS matrix and I-E matrix are used by matching the evaluation of internal and external factors that have been carried out at the input stage. Both of these matrices are chosen because their use is simple and commonly used in the process of formulating the strategy so that it is easier to implement it.

Internal-External Matrix (I-E)

\section{Results and Discussion}

\subsection{External factor evaluation}

After analyzing the external environment, a list of identified opportunities and threats are analyzed again in the external factor evaluation matrix, which is weighting for each factor. The value in weight is the result of multiplication of weights and ratings. Weights indicate the relative importance of these factors in achieving organizational goals. The total weight assigned to the above factor must be 1.0. While ranking is based on how the condition of shadow embroidery to external factors. Assessment 1-4, where 4 is given if an external factor matches (proportionally) to the shadow embroidery condition, a value of 3 is given if the external factor is not in accordance with the shadow embroidery condition, a value of 2 is given if the external factor is slightly in accordance with the shadow embroidery condition and the value is 1 if external factors are virtually nonexistent (conformity) with the shadow embroidered condition. 


\subsection{Internal factor evaluation}

An analysis of the internal environment that generates a list of strength and weakness factors is analyzed again in the internal factor evaluation matrix, which is weighted for each factor. The value in weight is the result of multiplication of weights and ratings. The total weight given to the above factor must be equal to 1.0. Regardless of whether the key factor is internal strength or weakness, the factors that are considered to have the greatest influence on organizational achievement, in this case is the shadow Sulam, given the highest weight.

Rankings 1 through 4 are assigned to each factor to indicate whether they represent major weaknesses (rank $=1)$, minor weakness (rank $=2)$, small strength (rank $=3$ ) or main strength (rank = 4). Ranking is given based on the state of the company. In this study the company is a shadow embroidery craft. So if an internal factor is a strength for the shadow embroidery then the factor is rated 3 or 4 (depending on the strength level) and if an internal factor is a weakness for the shadow embroidery then that factor is very weak.

\subsection{Matching phase}

At this matching stage, the formulation of the strategy uses two analyzes, namely using the IE matrix and SWOT matrix. The objective is to use two analyzes to produce strategies so that alternative strategies are more appropriate. Strategy formulation is based on the strengths, weaknesses, opportunities and threats that have been described at the input stage.

\subsubsection{Strategy formulation by using IE matrix}

Formulation of strategies with IE matrix based on weighting on the external factor evaluation matrix and internal factor matrix. The number of bobbies in the external factor evaluation matrix is 3.34 where the external factor evaluation of shadow embroidery has a strong value. The amount of weight on the internal factor evaluation matrix is 2.19 , which means the evaluation of the shadow embroidered internal factor has an average value. For more details, see table 1:

Based on the results of the IE matrix above, shadow embroidery is in cell II. According to Aulie Tsalistia, Rizal Syarief, [8] the divisions included in II are named in the Grow and Build position, the appropriate strategy to be implemented in this division is intensive 
TABLE 1: Matrik IE.

\begin{tabular}{|c|c|c|c|}
\hline \multicolumn{4}{|c|}{ EFI } \\
\hline 4,00 & 3,34 & 2,19 & 2,00 \\
\hline I & $\begin{array}{c}\text { II Sulam } \\
\text { Bayangan }\end{array}$ & III \\
\hline IV & V & VI \\
\hline VII & VIII & IX \\
\hline
\end{tabular}

or integral strategy. Intensive strategy can be done with market penetration (market Penetration Stategy), product development strategy and market development strategy, while integrative strategy with future integration, backward integration and horizontal integration

In shadow embroidery conditions, strategies that can be applied to intensive strategies and integrative strategies are:

1. Increase the number of salespeople by increasing the number of salespeople, increasing advertising budgets, offering vigorously various promotional items selling by maximizing the use of social media and making viral, or even increase publicity activities because at this time for promotional activities has not been made a special budget for the group of embroidery.

2. Utilizing simple technology to improve the quality and quantity of shadow embroidery

3. Modifying embroidery shadows into products other than clothing and mukena for it needed research and development and required cooperation with other product makers that can be applied this shadow embroidery.

\subsection{Strategy formulation using SWOT}

In addition to using the IE matrix, strategy formulation can be done using the SWOT matrix. This SWOT matrix uses external analysis and internal analysis in formulating strategy to be 4 categories ie SO Strategy, ST strategy, WO strategy and WT strategy.

According to Retnowati, [9] matching key external and internal factors is the biggest difficult part of developing a SWOT matrix and requires good judgment, and none of the best fit.

Strategy formulation using SWOT matrix for embroidery shadow. 
TABLE 2: SWOT matrix.

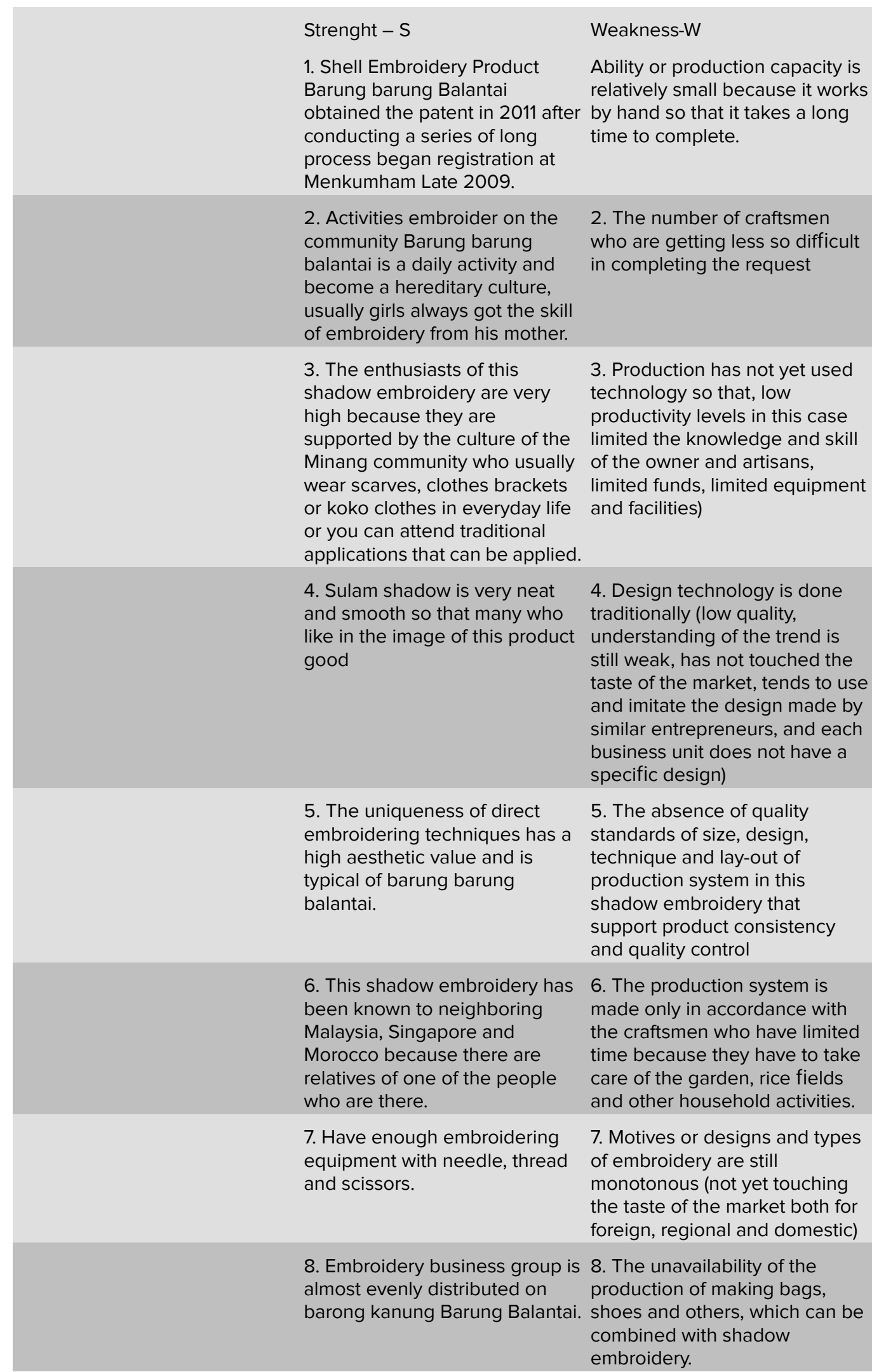




\begin{tabular}{|c|c|c|}
\hline & Strenght - S & Weakness-W \\
\hline & $\begin{array}{l}\text { 9. The availability of raw } \\
\text { material sources of alternative } \\
\text { fabrics with good quality that } \\
\text { can be used in the handicraft of } \\
\text { embroidery (such as: songket } \\
\text { cloth, cloth batik motifs are used } \\
\text { as application on this shadow } \\
\text { embroidery. }\end{array}$ & $\begin{array}{l}\text { 9. The competitiveness of } \\
\text { shadow embroidered products } \\
\text { is still low in domestic and } \\
\text { regional markets. }\end{array}$ \\
\hline & $\begin{array}{l}\text { 10. One group, Kagasa, won the } \\
\text { best design award } 2009 \text { Incraft } \\
\text { Award and UNESCO in } 2010 \text {. }\end{array}$ & $\begin{array}{l}\text { 10. Diversification of shadow } \\
\text { embroidery products does not } \\
\text { exist in the form of ready-made } \\
\text { clothing or supporting products } \\
\text { such as bags, shoes }\end{array}$ \\
\hline & $\begin{array}{l}\text { 11. The Southern Coastal } \\
\text { Government is concerned with } \\
\text { the continuity of the existence } \\
\text { of this shadow embroidery by } \\
\text { training the craftsmen through } \\
\text { the Department of Industry and } \\
\text { Trade and is a superior product } \\
\text { of the region. }\end{array}$ & $\begin{array}{l}\text { 11. The level of formal education } \\
\text { of craftsmen is low, so the } \\
\text { product is less creative and } \\
\text { innovative }\end{array}$ \\
\hline & $\begin{array}{l}\text { 12. Absorption of a high } \\
\text { workforce, especially women } \\
\text { craftsmen, starts at an unlimited } \\
\text { age as long as they are still able } \\
\text { to sew. }\end{array}$ & $\begin{array}{l}\text { 12. The ability of employers' } \\
\text { human resources (pemlik) is } \\
\text { generally less professional in } \\
\text { management (production } \\
\text { management, business } \\
\text { management, administration } \\
\text { and finance) }\end{array}$ \\
\hline & $\begin{array}{l}\text { 13. Location not too far from the } \\
\text { capital of Padang province } 45 \\
\text { Km approximately } 30-45 \\
\text { minutes away by car and very } \\
\text { good road access. }\end{array}$ & $\begin{array}{l}\text { 13. The skill of the craftsman's } \\
\text { human resource is still low, so } \\
\text { low quality and low productivity } \\
\text { (poorly trained designing and } \\
\text { embroidering technique }\end{array}$ \\
\hline & $\begin{array}{l}\text { 14. Patterns or designs that are } \\
\text { developed are typically sourced } \\
\text { from natural conditions around } \\
\text { Barung Barung Balantai such as } \\
\text { plant motifs. }\end{array}$ & $\begin{array}{l}\text { 14. Limited marketing still relies } \\
\text { on the local market and the lack } \\
\text { of cultivation of potential } \\
\text { markets especially neighboring } \\
\text { countries so that export value is } \\
\text { low }\end{array}$ \\
\hline & & $\begin{array}{l}\text { 15. Not yet the role of marketing } \\
\text { institutions: trading house, otlet, } \\
\text { or partnership of various sectors }\end{array}$ \\
\hline & & 16. After sales service is weak \\
\hline & & $\begin{array}{l}\text { 17. Weak research, monitoring } \\
\text { and market development }\end{array}$ \\
\hline & & $\begin{array}{l}\text { 18. Not yet established centers, } \\
\text { both formal and informal } \\
\text { centers that can support the } \\
\text { establishment of cooperative } \\
\text { institutions, marketing agencies, } \\
\text { or other business groups }\end{array}$ \\
\hline & & $\begin{array}{l}\text { 19. Investment funds and } \\
\text { working capital are limited }\end{array}$ \\
\hline Opportunity-O & SO strategy & WO strategy \\
\hline
\end{tabular}




\begin{tabular}{|c|c|c|}
\hline & Strenght - S & Weakness-W \\
\hline $\begin{array}{l}\text { 1. High demand for shadow } \\
\text { embroidery products for } \\
\text { domestic and Malay ethnic } \\
\text { groups (neighboring countries). }\end{array}$ & $\begin{array}{l}\text { 1. Make the most of social media } \\
\text { capabilities for promotion (O1, } \\
\mathrm{O} 2, \mathrm{O} 3, \mathrm{O}, \mathrm{O}, \mathrm{O} \text { ) so that the } \\
\text { general public knows the } \\
\text { existence and quality of shadow } \\
\text { embroidery (S1, S2, S3, S4, S5, } \\
\mathrm{S} 9, \mathrm{~S} 10, \mathrm{~S} 12, \mathrm{~S} 14 \text { ) }\end{array}$ & $\begin{array}{l}\text { 1. Utilizing existing skilled } \\
\text { manpower to coach the } \\
\text { craftsmen so that the number } \\
\text { increases to increase } \\
\text { production capacity and there is } \\
\text { a time cut in progress (W1, W2, } \\
\text { W3, W4, W5, W6, W7, O4) }\end{array}$ \\
\hline $\begin{array}{l}\text { 2. High need for all types of } \\
\text { embroidery products, especially } \\
\text { at special times such as } \\
\text { holidays: Eid, certain warnings. }\end{array}$ & $\begin{array}{l}\text { 2. Improving good relations with } \\
\text { local governments in the form of } \\
\text { continuous cooperation } \\
\text { because shadow embroidery is } \\
\text { a superior product of the South } \\
\text { Coast region }(\mathrm{O} 4, \mathrm{O}, \mathrm{O} 8) \text { to } \\
\text { maximize the potential that } \\
\text { exists in shadow embroidery } \\
\text { (S6, S7, S8, S11, S13) }\end{array}$ & $\begin{array}{l}\text { 2. Cooperate with other } \\
\text { industries that support seulam } \\
\text { shadows such as bags, shoes, } \\
\text { etc. through local government } \\
\text { (W8, W10) }\end{array}$ \\
\hline $\begin{array}{l}\text { 3. Globalization (the existence } \\
\text { of a very broad market } \\
\text { opportunity, both domestically } \\
\text { and internationally) }\end{array}$ & & $\begin{array}{l}\text { 3. Creating a shared container } \\
\text { or a kind of shadow embroidery } \\
\text { union may be a cooperative } \\
\text { institution, marketing agency or } \\
\text { other institution (W18, W19, O8) }\end{array}$ \\
\hline \multicolumn{3}{|l|}{$\begin{array}{l}\text { 4. Availability of skilled labor } \\
\text { that has not been utilized } \\
\text { optimally }\end{array}$} \\
\hline \multicolumn{3}{|l|}{$\begin{array}{l}\text { 5. Muslim fashion trends with } \\
\text { the term shar'i (opportunities to } \\
\text { increase productivity and } \\
\text { product diversification) }\end{array}$} \\
\hline $\begin{array}{l}\text { 6. Consumers who like } \\
\text { handicraft products (handmade) } \\
\text { especially made in the area is } \\
\text { increasing. }\end{array}$ & & \\
\hline
\end{tabular}

7. The location of Kanagarian barung barung balantai at the crossing to the capital of South Pesisir regency which is currently a regional tourist destination, national mandeh, increased marketing opportunities to open showrooms and promotions.

8. Local government policy supports this shadow embroidery by setting it as a superior product and on certain days local government employees must use this shadow embroidery in the work.

9. The progress of social media is very rapidly the opportunity to add media campaigns. 


\begin{tabular}{|c|c|c|}
\hline & Strenght - S & Weakness-W \\
\hline $\begin{array}{l}\text { 1. Domestic economic crisis or } \\
\text { world economic recession so } \\
\text { that people's purchasing power } \\
\text { decreases. }\end{array}$ & $\begin{array}{l}\text { 1. Conduct extensive research to } \\
\text { discover new or combined } \\
\text { methods for improving the } \\
\text { quality of the design with the } \\
\text { typical embroidered shadow } \\
\text { embroidery barung balantainya. }\end{array}$ & $\begin{array}{l}\text { 1. Improving the skill of } \\
\text { craftsmen in processing the } \\
\text { embroidery and skill of the } \\
\text { owner in managing his group } \\
\text { face competition with other } \\
\text { products. }\end{array}$ \\
\hline $\begin{array}{l}\text { 2. The quality of design and } \\
\text { diversification is low, the } \\
\text { product is saturated in the } \\
\text { market, so the level of } \\
\text { productivity decreases and the } \\
\text { production capacity is small }\end{array}$ & $\begin{array}{l}\text { 2. Improve the application of } \\
\text { embroidered shadows on other } \\
\text { products so that along with } \\
\text { fashion trends and all the } \\
\text { equipment. }\end{array}$ & $\begin{array}{l}\text { 2. Increase the use of } \\
\text { technology in the design and } \\
\text { development of motives }\end{array}$ \\
\hline \multicolumn{3}{|l|}{$\begin{array}{l}\text { 3. Attitudes in transfer payments } \\
\text { (used in online shops) are } \\
\text { increasing. }\end{array}$} \\
\hline \multicolumn{3}{|l|}{$\begin{array}{l}\text { 4. Product competition from } \\
\text { regional regions (other types of } \\
\text { embroidery in West Sumatra } \\
\text { and other provinces) }\end{array}$} \\
\hline \multicolumn{3}{|l|}{$\begin{array}{l}\text { 5. The type of embroidery } \\
\text { products in the form of kebaya, } \\
\text { baju kurung and Muslim clothes } \\
\text { are not marketable (because } \\
\text { today's female consumers tend } \\
\text { to like the form of ready-made } \\
\text { products }\end{array}$} \\
\hline $\begin{array}{l}\text { 6. Government funds for limited } \\
\text { embroidery }\end{array}$ & & \\
\hline
\end{tabular}

\section{Conclusion}

1. Utilize maximally social media capabilities for promotion so that the public knowledge of the existence and quality of embroidery shadow

2. Improving good relations with local government in the form of a continuous cooperation because shadow embroidery is a superior product of South Pesisir area in order to maximize the potential of the shadow embroidery

3. Utilizing existing skilled manpower to perform guidance on the craftsmen so that the number increases to increase production capacity and there is cutting time in workmanship

4. Cooperate with other industries that support shadow embroidery such as bags, shoes, etc. through local government

5. Creating a shared container or a kind of shadow embroidery union can be a cooperative institution, marketing agency or other institution 
6. Improving the skill of craftsmen in processing the embroidery and skill of the owner in managing his group face competition with other products.

7. Increase the use of technology in design and development

\section{Acknowledgement}

Praise the presence of Allah SWT for the blessings given so that the writer can complete this research, as well as the prayer and greetings to the Prophet Muhammad SAW. On this occasion the author expressed his gratitude to Director of AKBP Padang who have provided the opportunity for researchers to conduct research, thank to the craftsmen of the shadow embroidery of Kanagarian Barung-Barung Balantai for their cooperation.

\section{References}

[1] Cahyani, U. E. (2017). Analisis Strategi Pengembangan Agribisnis Salak Di Kabupaten Tapanuli Selatan. KOLEGIAL, 3(1), 36-50.

[2] Rika Desiyanti. (2016). Analisis Swot Dan Strategi Pengembangan Pada Keberhasilan Industri Kecil Rotan Kota Padang. Jurnal Apresiasi Ekonomi, 04, Nomor(Januari 2016), 1-14.

[3] Mawardi Bagindo, Bunasor Sanim, dan I. T. S. (2016). Model Bisnis Ekowisata di Taman Nasional Laut Bunaken dengan Pendekatan Business Model Canvas. Manajemen IKM, 11(1), 80-88.

[4] Emma Primadani, Endang Larasati S, A. S. (2013). Analisis Manajemen Strategi Pelestarian Dan Pengembangan Kawasan Kota Lama Sebagai Upaya Menuju Kawasan Wisata Budaya Di Kota Semarang. Jurusan Administrasi Publik Fakultas IImu Sosial Dan IImu Politik Universitas Diponegoro.

[5] Yulianti, D. (2014). Analisis Lingkungan Internal Dan Eksternal Dalam Pencapaian Tujuan Perusahaan (Studi Kasus di PT. Perkebunan Nusantara VII Lampung). Jurnal Sosiologi, 16(2), 103-114.

[6] Nyimas Ekinevita Putri, Retno Astuti, S. A. P. (2014). Perencanaan Strategi Pengembangan Restoran Menggunakan Analisis Swot Dan Metode QSPM (Quantitative Strategic Planning Matriks) (Studi Kasus Restoran Big Burger Malang). Jurnal Industria, 3(2), 93-106.

[7] Bima Iman Destratama, R. M. (2015). Analisis Strategi Pengembangan Pabrik Beras (PB.) Mulya Kencana Kecamatan Warungkondang Kabupaten Cianjur. Jurnal 
Agroscience, 5(2), 30-36.

[8] Aulie Tsalistia, Rizal Syarief, S. (2010). Kajian Program Misykat (Microfinance Syariah Berbasis Masyarakat) Sebagai Alternatif Pilihan Program Pemberdayaan Usaha Mikro (Studi Kasus pada Dompet Peduli Umat Daarut Tauhid Bogor). Manajemen IKM, 5(1), 12-21.

[9] Retnowati, N. D. (2004). Analisis CSF, SWOT dan TOWS Studi Kasus: PT Intan Pariwara Klaten. Jurnal Buana Informatika, 2(2), 31-37. 